\title{
Erratum to: Spring rainfall prediction based on remote linkage controlling using adaptive neuro-fuzzy inference system (ANFIS)
}

Gholam Abbas Fallah-Ghalhary • Majid Habibi-Nokhandan •

Mohammad Mousavi-Baygi • Javad Khoshhal • Akbar Shaemi Barzoki

Published online: 21 October 2009

(C) Springer-Verlag 2009

\section{Erratum to: Theor Appl Climatol}

DOI 10.1007/s00704-009-0194-x

In line 4 of the final paragraph before the Conclusion section, "RMSE of $505 \mathrm{~mm}$ " is incorrect and should read "RMSE of $5.43 \mathrm{~mm}$ ".

The online version of the original article can be found at http://dx.doi. org/10.1007/s00704-009-0194-x.

G. A. Fallah-Ghalhary $(\bowtie) \cdot$ J. Khoshhal

Department of Physical Geography, University of Isfahan,

Isfahan, Islamic Republic of Iran

e-mail: ab_fa789@yahoo.com

J. Khoshhal

e-mail: JavadKhoshhal@yahoo.com

G. A. Fallah-Ghalhary • M. Habibi-Nokhandan

Climatological Research Institute (CRI),

Mashhad, Islamic Republic of Iran

M. Habibi-Nokhandan

e-mail: habiby_2001@yahoo.com

M. Mousavi-Baygi

Department of Water Engineering,

Ferdowsi University of Mashhad,

Mashhad, Islamic Republic of Iran

e-mail: mousavi500@yahoo.com

A. Shaemi Barzoki

Department of Physical Geography,

Payam Noor University of Aran,

Aran, I.R. of Iran 